Situs Jurnal : http://ejournal.stiepancasetia.ac.id/index.php/iieb

Jilid 6 Nomor 2 Juli 2020

Hal 176 - 185

\title{
ANALISIS KEPATUHAN PERPAJAKAN PELAKU USAHA MIKRO, KECIL, DAN MENENGAH (UMKM) DI INDONESIA: STUDI PADA KOTA BANJARBARU KALIMANTAN SELATAN
}

\section{Raais Nurizzaman*, Amalia Kusuma Wardhani *, Noor Sfaifudin*}

Abstrak : Peran dan partisipasi seluruh pelaku UMKM di Indonesia dalam membayar pajak sangat diperlukan untuk pembanguan perekonomian Indonesia. Tujuan penelitian ini adalah (1) untuk menjelaskan tingkat pemahaman UMKM di Kota Banjarbaru terhadap peraturan perpajakan, (2) untuk mengeksplorasi rendahnya tingkat kepatuhan pajak dan penyebab rendahnya tingkat kepatuhan wajib pajak UMKM, (3) untuk menganalisis kefektivan kebijakan pemerintah tentang Peraturan Pemerintah Nomor 23 Tahun 2018, (4) untuk menganalisis peran apa saja yang telah dilakukan Pemerintah untuk meningkatkan kepatuhan UMKM dalam membayar pajak. Penelitian ini menggunakan pendekatan kualitatif deskriptif. Hasil penelitian ini menunjukkan bahwa UMKM di Kota Banjarbaru cukup baik dalam memahami peraturan perpajakan tentang peraturan No 23 Tahun 2018. Potensi kepatuhan UMKM di Kota Banjar Baru Kalimantan Selatan dalam membayar pajak masih rendah. Efektivitas PP No. 23 Tahun 2018 di Kota Banjarbaru belum bisa dikatakan efektif karena belum ada peningkatan wajib pajak UMKM yang signifikan. Upaya yang dilakukan pemerintah dalam meningkatkan kepatuhan wajib pajak adalah memberikan pelayanan yang baik kepada wajib pajak.

\section{Kata Kunci: UMKM, Kebijakan Fiskal, Kepatuhan Wajib Pajak, PP No 23 Tahun 2018}

\section{Latar Belakang}

Usaha, Kecil, Menengah (UMKM) memainkan peran yang sangat vital dalam pertumbuhan dan pembangunan ekonomi di Indonesia. Peranan yang dimiliki UMKM tidak hanya diakui di Indonesia sebagai negara berkembang tetapi juga di negaranegara maju.

Kontribusi UMKM terhadap Produk Domestik Bruto (PDB) tercatat mencapai 61,41 persen pada tahun 2018 (Gustomo, 2018). Dominasi UMKM dalam perekonomian setidaknya menyerap hampir 97\% total tenaga kerja nasional dan memiliki proporsi $99 \%$ dari total pelaku usaha di Indonesia. Akan tetapi, dalam sektor perpajakan, UMKM belum menunjukkan kontribusi yang dominan sebagaimana pengaruhnya terhadap pertumbuhan ekonomi dan penciptaan lapangan pekerjaan. Hal itu terjadi karena pengawasan yang dilakukan Direktorat jenderal pajak terhadap sektor UMKM masih belum dilakukan secara optimal dan kepatuhan pajak pelaku UMKM masih rendah (Anggara \& Sulistiyanti, 2017). Berdasarkan data Direktorat Jenderal Pajak (DJP), jumlah penerimaan pajak dari sektor UMKM pada tahun 2018 hanya sebesar Rp 5,7 triliun. Total penerimaan pajak yang mampu dikumpulkan DJP pada tahun 2018, sebesar Rp 1.315,93 triliun maka kontribusi dari UMKM hanya $0,43 \%$. Tidak hanya dari sisi jumlah kontribusi penerimaan pajak, jumlah wajib pajak UMKM masih sangat sedikit, yaitu hanya sebanyak 1,8 juta wajib pajak. Padahal, jumlah pelaku usaha UMKM mencapai $65 \%$ dari total pelaku usaha di Indonesia (Muc Consulting, 2019).

Lebih dari $70 \%$ penerimaan negara bersumber dari penerimaan pajak 
(Sudiartana \& Mendra, 2017). Oleh sebab itu peran dan partisipasi seluruh pelaku UMKM di Indonesia dalam membayar pajak sangat diperlukan, Titik berat dalam keberhasilan penarikan pajak UMKM adalah menumbuhkan tingkat kesadaran masyarakat pelaku UMKM sebagai wajib pajak untuk secara langsung dan bersamasama melaksanakan kewajiban perpajakan.

Sebagai upaya untuk meningkatkan penerimaan pajak dari sektor UMKM maka pada bulan Juli 2018, pemerintah menerbitkan aturan baru yaitu, PP 23 Tahun 2018 tentang Pajak Penghasilan atas Penghasilan Dari Usaha yang Diterima atau Diperoleh Wajib Pajak yang Memiliki Peredaran Bruto Tertentu. Inti dari peraturan pemerintah yang baru adlah tarif PPh Final UMKM diturunkan dari 1\% menjadi $0,5 \%$ yang dimuat dalam peraturan baru tersebut.

Sektor UMKM menjadi salah satu sektor yang mempengaruhi pertumbuhan ekonomi Banjarbaru. UMKM sangat berperan dalam pertumbuhan ekonomi di kota Banjarbaru karena selain berkonstribusi terhadap PDRB juga dapat memberikan lapangan kerja baik penduduk yang berada di Kota Banjarbaru maupun penduduk dari luar Kota Banjarbaru. Akan tetapi kontribusi UMKM di Kota Banjarbaru dari sector perpajakan masih kecil, hal ini dapat dilihat dari data statistik kepatuhan wajib pajak di Kota Banjarbaru pad Tabel 1.1 sebagai berikut:

Tabel 1.1

Statistik Kepatuhan Wajib Pajak Kota Banjarbaru

\begin{tabular}{|c|c|c|c|c|c|}
\hline & 2015 & 2016 & 2017 & 2018 & 2019 \\
\hline WP & 80,66 & 89,25 & 71,29 & 73,34 & 80,29 \\
\hline $\begin{array}{l}\text { Terdaftar } \\
\text { Wajib } \\
\text { SPT }\end{array}$ & 8 & 9 & 5 & 1 & 2 \\
\hline \multirow[t]{2}{*}{ - Badan } & 5,130 & 4,870 & 5,289 & 6,221 & 6,287 \\
\hline & 2015 & 2016 & 2017 & 2018 & 2019 \\
\hline Realisasi & 44,04 & 53,98 & 57,11 & 61,69 & 67,83 \\
\hline SPT & 0 & 7 & 3 & 5 & 5 \\
\hline \multirow[t]{2}{*}{ - Badan } & 2,814 & 2,389 & 3,462 & 3,095 & 3,439 \\
\hline & 2015 & 2016 & 2017 & 2018 & 2019 \\
\hline
\end{tabular}

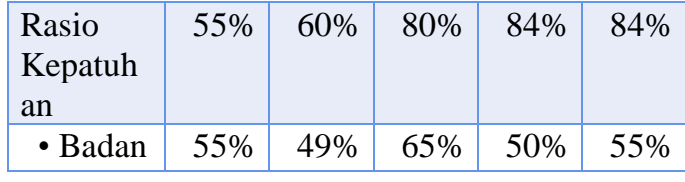

Sumber: KPP Pratama XYZ di

Provinsi Kalimantan Selatan

Berdasarkan Tabel 1.1 dapat diketahui jumlah wajib pajak yang terdaftar wajib SPT dari Tahun 2015 s/d 2019 cenderung mengalami penurunan. Berbeda dengan jumlah wajib pajak Badan wajib SPT yang cenderung mengalami peningkatan. Akan tetapi rasio kepatuhan wajib pajak Badan wajib SPT masih rendah. Pada Tahun 2019 rasio kepatuhan wajib pajak Badan wajib SPT hanya 55\%. Berdasrkan uraian diatas maka peneliti tertarik untuk menganalisis Kepatuhan Perpajakan Pelaku Usaha Mikro, Kecil, Dan Menengah Di Indonesia( Studi Pada Kota Banjarbaru Kalimantan Selatan).

Adapun masalah yang menarik untuk dibedah antara lain :

1. Bagaimana tingkat pemahaman UMKM di Kota Banjarbaru terhadap peraturan perpajakan?

2. Mengapa tingkat kepatuhan rendah dan apa penyebab rendahnya tingkat kepatuhan wajib pajak UMKM di Kota Banjarbaru Kalimantan Selatan?

3. Bagaimana kefektivan kebijakan pemerintah tentang Peraturan Pemerintah Nomor 23 Tahun 2018?

4. Peran apa saja yang telah dilakukan Pemerintah untuk meningkatkan kepatuhan UMKM?

\section{Kajian Literatur}

Kebijakan Fiskal

Kebijakan Fiskal dalam arti sempit disebut sebagai kebijakan pajak, dimana kebijakan pajak sebagai suatu sarana peningkatan pendapatan negara dan retribusi (Gunadi, Millla, \& Wisamodro, 2010). Kebijakan fiskal menurut Mankiw (2013) dalam Setiawan (2018) definisikan sebagai kebijakan ekonomi yang digunakan oleh pemerintah untuk mengelola / mengarahkan perekonomian ke kondisi 
yang lebih baik atau diinginkan dengan cara mengubah-ubah penerimaan dan belanja pemerintah. Kebijakan fiskal bertujuan untuk mengarahkan perekonomian ke arah yang lebih baik yang ditandai dengan pertumbuhan ekonomi dan kesejahteraan masyarakat (welfare economics) (Setiawan, 2018). Definisi Pajak

Pajak adalah iuran masyarakat kepada Negara (yang dipaksakan) yang terutang oleh yang wajib membayarnya menurut peraturan-peraturan umum (undangundang) dengan tidak mendapat prestasi kembali yang langsung dapat ditunjuk dan yang gunanya adalah untuk membiayai pengeluaran-pengeluaran umum berhubung tugas Negara untuk menyelenggarakan pemerintahan (Waluyo, 2013). Sedangkan berdasarkan Undang-Undang Nomor 28 tahun 2007 Perubahan Ketiga Atas UndangUndang Nomor 6 Tahun 1983 Tentang Ketentuan Umum Dan Tata Cara Perpajakan menyatakan bahwa "Pajak adalah kontribusi wajib kepada negara yang terutang oleh orang pribadi atau badan yang bersifat memaksa berdasarkan undangundang, dengan tidak mendapatkan imbalan secara langsung dan digunakan untuk keperluan negara bagi sebesar-besarnya kemakmuran rakyat.

\section{Definisi Wajib Pajak}

Berdasarkan Undang-undang Nomor 28 Tahun 2007 Perubahan Ketiga Atas Undang-Undang Nomor 6 Tahun 1983 Tentang Ketentuan Umum dan Tata Cara Perpajakan Pasal 1 ayat 2, Wajib Pajak adalah Orang Pribadi atau Badan, meliputi pembayar pajak, pemotong pajak, dan pemungut pajak yang mempunyai hak dan kewajiban perpajakan sesuai dengan ketentuan Peraturan Perundang-undangan perpajakan.

\section{Pemahaman Peraturan Perpajakan}

Pemahaman peraturan perpajakan adalah cara wajib pajak dalam memahami peraturan perpajakan yang telah ada (As'ari \& Erawati, 2018). Pemahaman wajib pajak terhadap peraturan perpajakan adalah cara wajib pajak dalam memahami peraturan perpajakan yang telah ada (Hardiningsih dan Yuliananwati, 2011) dalam (As'ari \& Erawati, 2018). Berdasarkan pengertian diatas maka dapat dikatakan bahwa pemahaman peraturan perpajakan merupakan pemahaman dan pengetahuan yang dimiliki wajib pajak tentang peraturan dan undang-undang perpajakan serta penerapannya dalam melakukan kegiatan perpajakan seperti, membayar pajak, melaporkan SPT, dan sebagainya.

Kepatuhan Wajib Pajak

Pengertian kepatuhan Wajib Pajak dikutip oleh Rahayu (2010) adalah kewajiban Wajib Pajak dalam mendaftarkan diri, kepatuhan untuk menyetorkan kembali Surat pemberitahuan, kepatuhan dalam perhitungan dan pembayaran pajak terutang, kepatuhan dalam pembayaran tunggakan. Menurut Menteri Keuangan No.544/KMK.04/2000 menyatakan bahwa "Kepatuhan perpajakan adalah tindakan WP dalam pemenuhan kewajiban perpajakannya sesuai dengan ketentuan peraturan perundang-undangan dan peraturan pelaksanaan perpajakan yang berlaku dalam suatu negara".

\section{Usaha Mikro Kecil dan Menengah (UMKM)}

Berdasarkan Undang-Undang Nomor 20 Tahun 2008 tentang Usaha Mikro, Kecil dan Menengah (UMKM), maka pengertian dari UMKM adalah sebagai berikut:

a. Usaha Mikro adalah usaha produktif milik orang perorangan dan/atau badan usaha perorangan yang memenuhi kriteria Usaha Mikro sebagaimana diatur dalam Undang-Undang.

b. Usaha Kecil adalah usaha ekonomi produktif yang berdiri sendiri, yang dilakukan oleh orang perorangan atau badan usaha yang bukan merupakan anak perusahaan atau bukan cabang perusahaan yang dimiliki, 
dikuasai, atau menjadi bagian baik langsung maupun tidak langsung dari usaha menengah atau usaha besar yang memenuhi kriteria Usaha Kecil sebagaimana dimaksud dalam Undang-Undang.

c. Usaha Menengah adalah usaha ekonomi produktif yang berdiri sendiri, yang dilakukan oleh orang perseorangan atau badan usaha yang bukan merupakan anak perusahaan atau cabang perusahaan yang dimiliki, dikuasai, atau menjadi bagian baik langsung maupun tidak langsung dengan Usaha Kecil atau usaha besar dengan jumlah kekayaan bersih atau hasil penjualan tahunan sebagaimana diatur dalam Undang-Undang.

\section{Metode Penelitian}

Penelitian yang akan dilakukan menggunakan metode penelitian kualitatif yang bertujuan untuk memahami obyek yang diteliti secara mendalam. Menurut (Sugiyono, 2013) metode penelitian kualitatif adalah metode penelitian yang digunakan untuk meneliti pada kondisi objek yang alamiah, (sebagai lawannya adalah eksperimen) dimana peneliti adalah sebagai instrumen kunci, teknik pengumpulan data dilakukan secara trianggulasi (gabungan), analisis data bersifat induktif, dan hasil penelitian kualitatif lebih menekankan makna dari pada generalisasi.

Pendekatan ini digunakan untuk mendapatkan pemahaman yang luas dan mendalam mengenai analisis Kepatuhan Perpajakan Pelaku Usaha Mikro, Kecil, Dan Menengah di Kota Banjarbaru Kalimantan Selatan. Penelitian Kualitatif disebut juga sebagai pemahaman mendalam karena mempertanyakan makna suatu objek secara mendalam dan luas.

\section{Hasil Penelitian dan Pembahasan}

\section{Profil Partisipan}

Wawancara dilakukan dengan pola semiterstruktur untuk menggali persepsi dan menceritakan pengalaman pelaku UMKM yang bersinggungan dengan pajak. Wawancara dilakukan dengan partisipan yang menjadi pengurus atau aktif di paguyuban atau klaster 7 bidang usaha yang meliputi bidang fashion, properti, peternakan, kuliner, mebel, jasa, dan perdagangan. Wawancara pendahuluan terkait dengan profil partisipan dengan pertanyaan (a) Sebutkan Nama/UMKM Bapak Ibu, (b) Sejak kapan mendirikan usaha ini?, (c) Apa bidang usaha bapak ibu ?, (d) Apakah Bapak/ Ibu memiliki NPWP? (e) Sejak kapan menjadi wajib pajak? Jawaban dari pertanyaan yang peneliti ajukan kepada partisipan agar mudah dipahami, maka peneliti rangkum dalam Tabel 1.2 dibawah ini:

\section{Tabel 1.2 Profil Partisipan}

\begin{tabular}{|c|c|c|c|c|c|c|}
\hline $\begin{array}{l}\mathbf{N} \\
\mathbf{0}\end{array}$ & $\begin{array}{l}\text { (1) } \\
\text { Nama } \\
\text { Partisipa } \\
\text { n/ } \\
\text { UMKM/ } \\
\text { Perusaha } \\
\text { an } \\
\end{array}$ & $\begin{array}{l}\text { (2) } \\
\text { Tahun } \\
\text { Pendiri } \\
\text { an } \\
\text { Usaha }\end{array}$ & \begin{tabular}{|l}
$(3)$ \\
$\mathrm{Bi}$ \\
$\mathrm{da}$ \\
$\mathrm{ng}$ \\
$\mathrm{Us}$ \\
$\mathrm{ah}$ \\
$\mathrm{a}$ \\
\end{tabular} & $\begin{array}{l}\text { (4) } \\
\text { Kepemilikan } \\
\text { NPWP }\end{array}$ & $\begin{array}{l}(5) \\
\text { Wakt } \\
\text { u } \\
\text { menja } \\
\text { di } \\
\text { wajib } \\
\text { pajak } \\
\end{array}$ & \begin{tabular}{|l}
$(6)$ \\
Kriter \\
ia \\
Kepat \\
uhan
\end{tabular} \\
\hline 1 & Partisipan I & 2015 & $\begin{array}{l}\text { Prope } \\
\text { rti }\end{array}$ & Memiliki NPWP & 2016 & Tertib \\
\hline 2 & Partisipan 2 & 2018 & $\begin{array}{l}\text { Peter } \\
\text { naka } \\
\text { n }\end{array}$ & Memiliki NPWP & 2019 & Telat \\
\hline 3 & Partisipan 3 & 2018 & $\begin{array}{l}\text { Kulin } \\
\text { er }\end{array}$ & Memiliki NPWP & 2019 & Telat \\
\hline 4 & Partisipan 4 & 2017 & $\begin{array}{l}\text { Fashi } \\
\text { on }\end{array}$ & Memiliki NPWP & 2018 & Telat \\
\hline 5 & Partisipan 5 & 2016 & $\begin{array}{l}\text { Kulin } \\
\text { er }\end{array}$ & Memiliki NPWP & 2017 & Tertib \\
\hline 6 & Partisipan 6 & 2010 & $\begin{array}{l}\text { Perda } \\
\text { gang } \\
\text { an }\end{array}$ & Memiliki NPWP & 2012 & Tertib \\
\hline 7 & Partisipan 7 & 2017 & $\begin{array}{l}\text { Kulin } \\
\text { er }\end{array}$ & Memiliki NPWP & 2017 & Tertib \\
\hline 8 & Partisipan 8 & 2019 & $\begin{array}{l}\text { Peter } \\
\text { naka } \\
\text { n }\end{array}$ & Memiliki NPWP & 2019 & Tertib \\
\hline 9 & Partisipan 9 & 2013 & \begin{tabular}{|l|} 
Perda \\
gang \\
an
\end{tabular} & Memiliki NPWP & 2013 & Tertib \\
\hline & $\begin{array}{l}\text { Partisipan } \\
10\end{array}$ & 2019 & \begin{tabular}{|l|} 
Perda \\
gang \\
an
\end{tabular} & Memiliki NPWP & 2019 & Tertib \\
\hline & $\begin{array}{l}\text { Partisipan } \\
11\end{array}$ & 2018 & \begin{tabular}{|l|} 
Furni \\
ture
\end{tabular} & Memiliki NPWP & 2019 & Tertib \\
\hline & $\begin{array}{l}\text { Partisipan } \\
12\end{array}$ & 2018 & $\begin{array}{l}\text { Peter } \\
\text { naka } \\
\text { n }\end{array}$ & $\begin{array}{lr}\text { Belum } & \text { memiliki } \\
\text { NPWP, } & \\
\text { Baru } & \text { membuat } \\
\text { NPWP } & \text { karena mau }\end{array}$ & & $\begin{array}{l}\text { Tidak } \\
\text { memb } \\
\text { ayar }\end{array}$ \\
\hline
\end{tabular}




\begin{tabular}{|c|c|c|c|c|c|c|}
\hline & & & & $\begin{array}{l}\text { pinjam uang ke } \\
\text { Bank }\end{array}$ & & \\
\hline 13 & $\begin{array}{l}\text { Partisipan } \\
13\end{array}$ & 2018 & $\begin{array}{l}\text { Perda } \\
\text { gang } \\
\text { an }\end{array}$ & $\begin{array}{l}\text { Belum } \\
\text { NPWP, } \\
\text { membuat } \quad \text { NPWP } \\
\text { karena mau pinjam } \\
\text { uang ke Bank }\end{array}$ & & $\begin{array}{l}\text { Tidak } \\
\text { memb } \\
\text { ayar } \\
\text { pajak }\end{array}$ \\
\hline 14 & $\begin{array}{l}\text { Partisipan } \\
14\end{array}$ & 2017 & Jasa & Memiliki NPWP & 2018 & $\begin{array}{l}\text { Tertib } \\
\text { prata }\end{array}$ \\
\hline 15 & $\begin{array}{l}\text { Partisipan } \\
15\end{array}$ & 2017 & $\begin{array}{l}\text { Fashi } \\
\text { on }\end{array}$ & $\begin{array}{lr}\text { Belum } & \text { memiliki } \\
\text { NPWP, } & \text { Baru } \\
\text { membuat } & \text { NPWP } \\
\text { karena } & \text { mau } \\
\text { mengajukan } & \text { kredit } \\
\text { rumah } & \end{array}$ & & $\begin{array}{l}\text { Tidak } \\
\text { memb } \\
\text { ayar } \\
\text { pajak }\end{array}$ \\
\hline 16 & $\begin{array}{l}\text { Partisipan } \\
16\end{array}$ & 2015 & $\begin{array}{l}\text { Perda } \\
\text { gang } \\
\text { an }\end{array}$ & $\begin{array}{l}\text { Baru memiliki } \\
\text { NPWP di awal } \\
\text { tahun 2020, }\end{array}$ & & $\begin{array}{l}\text { Belum } \\
\text { memb } \\
\text { ayar }\end{array}$ \\
\hline 17 & $\begin{array}{l}\text { Partisipan } \\
17\end{array}$ & 2014 & Jasa & $\begin{array}{lr}\text { Belum } & \text { memiliki } \\
\text { NPWP, } & \text { Baru } \\
\text { membuat } & \text { NPWP } \\
\text { karena } & \text { mau } \\
\text { mengajukan } & \text { kredit } \\
\text { rumah } & \end{array}$ & & $\begin{array}{l}\text { Tidak } \\
\text { memb } \\
\text { ayar } \\
\text { pajak }\end{array}$ \\
\hline 18 & $\begin{array}{l}\text { Partisipan } \\
18\end{array}$ & 2017 & $\begin{array}{l}\text { Kulin } \\
\text { er }\end{array}$ & $\begin{array}{lr}\text { Belum } & \text { memiliki } \\
\text { NPWP, } & \text { Baru } \\
\text { membuat } & \text { NPWP } \\
\text { karena mau pinjam } \\
\text { uang ke Bank }\end{array}$ & & $\begin{array}{l}\text { Tidak } \\
\text { memb } \\
\text { ayar } \\
\text { pajak }\end{array}$ \\
\hline 19 & $\begin{array}{l}\text { Partisipan } \\
19\end{array}$ & 2017 & Jasa & $\begin{array}{l}\text { Belum memiliki } \\
\text { NPWP, } \\
\text { membuat NPWP } \\
\text { karena mau pinjam } \\
\text { uang ke Bank }\end{array}$ & & $\begin{array}{l}\text { Tidak } \\
\text { memb } \\
\text { ayar } \\
\text { pajak }\end{array}$ \\
\hline & $\begin{array}{l}\text { Partisipan } \\
20\end{array}$ & 2015 & Jasa & $\begin{array}{l}\text { Belum memiliki } \\
\text { NPWP, } \\
\text { membuat NPWP } \\
\text { karena mau pinjam } \\
\text { uang ke Bank }\end{array}$ & & $\begin{array}{l}\text { Tidak } \\
\text { memb } \\
\text { ayar } \\
\text { pajak }\end{array}$ \\
\hline
\end{tabular}

Berdasarkan hasil wawancara diatas dapat dikatakan bahwa perilaku pelaku UMKM mendaftarkan diri untuk memperoleh NPWP didorong oleh kekuasaan yang bersifat memaksa dari pemerintah (power of authority). Kepatuhan oleh karena ada kekuatan dari pihak yang memaksa atau enforced compliance tersebut bukan berupa pemeriksaan pajak atau pengenaan sanksi sebagaimana menurut Kirchler (2007) dalam Suwardi (2018), melainkan pemaksaan yang melibatkan pihak ketiga (withholding) berupa persyaratan perijinan usaha, pengajuan kredit dan persyaratan untuk bertransaksi dengan bendaharawan pemerintah.

\section{Pemahaman UMKM Kota Banjarbaru Terhadap Peraturan Perpajakan}

Mengingat begitu pentingnya pengetahuan tentang PP No 23 Tahun 2018 bagi UMKM, peneliti mewawancari 20 UMKM di Kota Banjar Baru terkait pengetahuannya tentang PP No 23 Tahun 2018. Berikut kutipan hasil wawancara dengan para partisipan:

Tabel 1.3 Hasil Wawancara

Pemahaman PP No 23 Tahun 2018

\begin{tabular}{|c|c|}
\hline Partp & Petanyaan dan jawaban \\
\hline & $\begin{array}{l}\text { Apakah Bapak Ibu pernah memperoleh penjelasan } \\
\text { terkait dengan PP No } 23 \text { Tahun 2018? Apa yang } \\
\text { Bapak Ibu pahami terkait dengan PP No } 23 \text { Tahun } \\
2018 \text { ? }\end{array}$ \\
\hline 1 & $\begin{array}{l}\text { Pernah kami diundang sosialisai pak sekali, adanya } \\
\text { potongan pajak pak }\end{array}$ \\
\hline 2 & $\begin{array}{l}\text { Pernah pak, diberi tahu saja sih pak saat bikin NPWP } \\
\text { pertama kali, katanya ada potongan pajak jadi } 0,5 \% \\
\text { pak }\end{array}$ \\
\hline 3 & $\begin{array}{l}\text { Diberi tahu saja sih pak saat bikin NPWP pertama } \\
\text { kali kalau ada perturan baru, adanya penurunan } \\
\text { pajak }\end{array}$ \\
\hline 4 & $\begin{array}{l}\text { Pernah sekali pak, yang saya pahami PP tersebut } \\
\text { mengatur tentang penurunan pajak dari } 1 \% \text { menjadi } \\
0,5 \% \text { Pak }\end{array}$ \\
\hline 5 & $\begin{array}{l}\text { Tidak pernah pak, } \\
\text { Saya hanya bayar aja Pak, ke kantor selesai, } \\
\text { pokoknya terima beres }\end{array}$ \\
\hline 6 & Pernah sekali pak, tentang penurunan pajak \\
\hline 7 & Tidak pernah Pak \\
\hline 8 & $\begin{array}{l}\text { Waktu daftar NPWP diberitahu, katanya nanti kalau } \\
\text { bayar pajak dapat potongan } 0,5 \%\end{array}$ \\
\hline 9 & $\begin{array}{l}\text { Pernah pak,sekali, PP tersebut mengatur tentang } \\
\text { pemotongan pajak dari } 1 \% \text { menjadi } 0,5 \% \text { Pak }\end{array}$ \\
\hline 10 & $\begin{array}{l}\text { Pernah pak, dikumpulin dikantor, Saya paham nya } \\
\text { dapat potongan pajak Pak }\end{array}$ \\
\hline 11 & $\begin{array}{l}\text { Pernah pak, dijelaskan kalau ada aturan baru tentang } \\
\text { penurunan pajak }\end{array}$ \\
\hline 12 & $\begin{array}{l}\text { Pernah pak, pemahaman saya pemerintah } \\
\text { mengeluarkan peraturan tentang pemangkasan tariff } \\
\text { pajak penghasilan } \mathrm{PPh} \text { dari } 1 \% \text { menjadi } 0,5 \% \mathrm{Pak}\end{array}$ \\
\hline 13 & $\begin{array}{l}\text { Pernah pak, kalau membayar pajak akan } \\
\text { memperoleh pemotongan dari } 1 \% \text { menjadi } 0,5 \%\end{array}$ \\
\hline 14 & $\begin{array}{l}\text { Pernah pak, yang saya pahami adalah pemerintah } \\
\text { memberi keringan membayar pajak } \mathrm{PPh} 0,5 \%\end{array}$ \\
\hline 15 & Pernah pak, katanya dapat potongan pajak \\
\hline 16 & Belum pernah \\
\hline 17 & $\begin{array}{l}\text { Pernah } 2 \text { kali ikut pak, pemerintah mengeluarkan } \\
\text { peraturan baru untuk menggantikan peraturan } \\
\text { sebelumnya tentang potongan pembayaran pajak } \\
\text { dari } 1 \% \text { jadi } 0,5 \%\end{array}$ \\
\hline 18 & Pernah Pak, dapat potongan pembayaran pajak \\
\hline 19 & $\begin{array}{l}\text { Pernah Pak, jika bayar pajak akan dapat pemotongan } \\
0,5 \%\end{array}$ \\
\hline 20 & BELUM PERNAH \\
\hline
\end{tabular}

Berdasarkan Tabel 1.3 diketahui bahwa $80 \%$ partisipan pernah memperoleh penjelasan tentang PP No 23 Tahun 2018. Berdasarkan kutipan hasil wawancara diatas, partisipan memahami PP No 23 Tahun 2018 hanya sebatas pada aturan pemangkasan atau pemotongan pajak $\mathrm{PPh}$ dari $1 \%$ menjadi $0,5 \%$. Hasil wawancara 
menunjukkan bahwa partisipan memahami PP No 23 Tahun 2018 belum secara detail. Partisipan menerima penjelasan tentang PP ini saat mereka mengajukan NPWP.

\section{Tingkat Kepatuhan Pembayaran Pajak Pelaku UMKM di Kota Banjar Baru}

Tingkat kepatuhan wajib pajak Badan wajib SPT masih rendah, meskipun mereka cukup baik dalam memahami tentang peraturan perpajakan. Hal tersebut terlihat dalam hasil wawancara sebagai berikut.

\section{Tabel 1.4 Hasil Wwancara Kepatuhan} Dalam Membayar Pajak

\begin{tabular}{|c|l|}
\hline Partp & \multicolumn{1}{|c|}{ Petanyaan dan jawaban } \\
\hline & $\begin{array}{l}\text { Apakah Bapak/Ibu tepat waktu dalam proses pembayaran } \\
\text { dan pelaporan pajak? }\end{array}$ \\
\hline 1 & Saya selalu lapor tepat waktu Pak \\
\hline 2 & Sering telat Pak, \\
\hline 3 & Sering telat Pak \\
\hline 4 & Sering telat Pak \\
\hline 5 & lapor dan bayar waktu awal tahun saja pak \\
\hline 6 & tepat waktu pak \\
\hline 7 & saya hanya lapor dan bayar tahunan sekali pak \\
\hline 8 & saya bayar tiap bulan dan lapor tahuna tepat waktu \\
\hline 9 & Bayar tiap bulan, lapor awal tahun pak \\
\hline 10 & lapor dan bayar sekali setahun pak \\
\hline 11 & bayar tiap bulan saya pak, supaya akhir tahun ringan \\
\hline 12 & $\begin{array}{l}\text { Tidak membayar pajak, Baru membuat NPWP karena mau } \\
\text { pinjam uang ke Bank }\end{array}$ \\
\hline 13 & $\begin{array}{l}\text { Tidak membayar pajak, Belum memiliki NPWP, Baru } \\
\text { membuat NPWP karena mau pinjam uang ke Bank }\end{array}$ \\
\hline 14 & $\begin{array}{l}\text { saya tiap bulan bayar langsung melalui atm pak, dan tidap } \\
\text { Tahun saya lapor tepat waktu }\end{array}$ \\
\hline 15 & $\begin{array}{l}\text { Tidak membayar pajak, Belum memiliki NPWP, Baru } \\
\text { membuat NPWP karena mau mengajukan kredit rumah }\end{array}$ \\
\hline 16 & $\begin{array}{l}\text { Tidak Bayar pajak, untuk bulan April ini belum, karena } \\
\text { usahanya tutup dan minus di kondisi saat ini. Eh diluar } \\
\text { dugaan setelah urus legalitas usahanya down, jadi fokus } \\
\text { cari pemasukan dulu untuk kebutuhan sehari-hari. Say } \\
\text { memiliki NPWP baru pada tahun 2020, baru tahu NPWP } \\
\text { tahun 2018, sebelumnya tidak paham sama sekali tentang } \\
\text { pajak, karena tidak pernah mendapat edukasi tentang } \\
\text { perpajakan. Basik pendidikan juga pesantren jadi kurang } \\
\text { tau mengenai itu, karena ingin memiliki legalitas usaha } \\
\text { harus bikin NPWP” }\end{array}$ \\
\hline 17 & $\begin{array}{l}\text { Tidak membayar pajak, Baru membuat NPWP karena mau } \\
\text { beli rumah }\end{array}$ \\
\hline 18 & $\begin{array}{l}\text { Tidak membayar pajak, Baru membuat NPWP karena mau } \\
\text { pinjam uang ke Bank }\end{array}$ \\
\hline 19 & $\begin{array}{l}\text { Tidak membayar pajak, Baru membuat NPWP karena mau } \\
\text { pinjam uang ke Bank }\end{array}$ \\
\hline 20 & $\begin{array}{l}\text { Tidak membayar pajak, Baru membuat NPWP karena mau } \\
\text { pinjam uang ke Bank }\end{array}$ \\
\hline 32 & dasatkan Tabel 1.4 dilketahui bahWa \\
\hline
\end{tabular}

Berdasarkan Tabel 1.4 diketahui bahwa 13 partisipan sudah memiliki NPWP, 9 menyatakan tertib dalam melakukan pembayaran pajak, 3 partisipan menyatakan telat dalam membayar pajak, 1 partisipan belum membayar pajak karena baru memiliki NPWP di 2020. Sisanya 7 partisipan tidak membayar pajak, mereka baru mengajukan NPWP karena mereka butuh untuk memenuhi syarat administrasi pengajuan pinjaman ke Bank dan syarat administrasi untuk membeli rumah.

\section{Faktor Yang Mempengaruhi Tingkat Kepatuhan Wajib Pajak}

Berikut kutipan hasil wawancara terhadap partisipan yang telat membayar pajak dan tidak membayar pajak.

\section{Tabel 1.5 Faktor Yang Mempengaruhi Kepatuhan Wajib Pajak}

\begin{tabular}{|l|l|}
\hline Partp & \multicolumn{1}{|c|}{ Petanyaan dan jawaban } \\
\hline & $\begin{array}{l}\text { Beberapa kasus korupsi yang diberitakan } \\
\text { dimedia masa menyebabkan menurunnya } \\
\text { kepercayaan masyarakat terhadap pegawai } \\
\text { pajak, apakah hal ini mempengaruhi Bapak } \\
\text { Ibu dalam pemenuhan kewajiban perpajakan } \\
\text { seperti membayar dan melaporkan pajak? }\end{array}$ \\
\hline 2 & $\begin{array}{l}\text { Pak, Saya sering telat bayar karena lupa kalau } \\
\text { sudah waktunya bayar pajak. Kalau kasus } \\
\text { korupsi, saya jengkel pak, kita disuruh bayar } \\
\text { pajak kalau telat didenda eeee,,,malah } \\
\text { dikorupsi. }\end{array}$ \\
\hline 3 & $\begin{array}{l}\text { Korupsi kadang membuat saya enggan } \\
\text { meloprkan pajak saya pak, tapi kalau gak } \\
\text { lapor atau bayar malah kita dikejar sama } \\
\text { petugas pajak Pak }\end{array}$ \\
\hline 4 & $\begin{array}{l}\text { Iya pak, kita bayar pajak, uangnya dikorupsi, } \\
\text { harusnya kan dikembalikan lagi untuk } \\
\text { kepentingan rakyat, }\end{array}$ \\
\hline 12 & $\begin{array}{l}\text { Iya pak, saya juga belum paham dengan pajak } \\
\text { Tidak Pak, itu urusannya yang korupsi, saya } \\
\text { enggan melaporkan pendapatan saya pak, } \\
\text { nanti dikejar-kejar petugas pajak }\end{array}$ \\
\hline 13 & $\begin{array}{l}\text { Kalau dipikir-pikir ya, terpengaruh pak, } \\
\text { sudah bayar pajak e malah dikorupsi, mending } \\
\text { gak bayar pajak sekalian, }\end{array}$ \\
\hline 16 & $\begin{array}{l}\text { Saya no coment denga korupsi pak, dosa } \\
\text { ditanggung sendiri, harusnya ya jangan } \\
\text { dikorupsi. }\end{array}$ \\
\hline 17 & $\begin{array}{l}\text { sebel saja sih pak, tapi kalau kita tidak bayar } \\
\text { malah dipriksa nanti }\end{array}$ \\
\hline 19 & ya jadi tidak ikhlas saja sih pak bayar pajak \\
baik- baik pak,,,, \\
kadang ya sebel sih pak, \\
Berdasarkan hasil
\end{tabular}

Berdasarkan hasil wawancara diatas faktor yang menyebabkan partisipan tidak tertib dalam membayar pajak adalah sebagai berikut: 
1) Anggapan petugas pajak yang dianggap masih korup (karena kasus masa lalu gayus tambunan, dll) menyebabkan mereka enggan membayar pajak.

2) Kesadaran dalam membayar pajak masih rendah.

3) Kondisi ekonomi yang tidak mendukung untuk membayar pajak.

\section{Kefektifan kebijakan pemerintah tentang Peraturan Pemerintah Nomor 23 Tahun 2018}

Pemerintah telah menerbitkan kebijakan penurunan tarif $\mathrm{PPh}$ final dari $1 \%$ menjadi $0,5 \%$ bagi pelaku UMKM. Aturan tersebut dituangkan dalam Peraturan Pemerintah (PP) No.23/ 2018 yang diberlakukan secara efektif per 1 Juli 2018.

Tabel 1.6 Hasil Wwancara Kepatuhan Dalam Membayar Pajak

\begin{tabular}{|l|l|}
\hline Partp & \multicolumn{1}{|c|}{ Petanyaan dan jawaban } \\
\hline & $\begin{array}{l}\text { Tujuan dikeluarkannya PP No. 23 tahun } \\
2018 \text { adalah untuk menurunkan pajak, tarif } \\
\text { PPh Final UMKM diturunkan dari 1\% } \\
\text { menjadi 0,5\% yang dimuat dalam } \\
\text { peraturan baru tersebut. Bagaimana } \\
\text { pendapat Bapak/ Ibu terhadap kemudahan } \\
\text { dan penyederhanaan pajak pada PP No.23 } \\
\text { Tahun 2018? }\end{array}$ \\
\hline 1 & $\begin{array}{l}\text { lebih meringankan, karena bisa kita bayar } \\
\text { tiap bulan, jadi di akhir tahun tidak perlu } \\
\text { bayar lagi }\end{array}$ \\
\hline 2 & $\begin{array}{l}\text { sebenarnya ringan pak, namun karena } \\
\text { kami bayar setahun sekali jadi ya lumayan } \\
\text { sih pak }\end{array}$ \\
\hline 3 & menjadi lebioh ringan pak \\
\hline 4 & ringan pajk, tinggal kali 0.5\% dari omzet \\
\hline 5 & sangat meringankan, karena sebelumnya \\
\hline 6 & tarif 1 \% \\
\hline 7 & lebih meringankan dari Tahun sebelumnya \\
\hline 8 & sangat meringankan \\
\hline 9 & sangat meringankan \\
\hline 10 & sangat meringankan \\
\hline 11 & sangat meringankan \\
\hline 12 & sangat meringankan \\
\hline 13 & sangat meringankan karena 0,5 \\
\hline 14 & omzet \\
\hline 15 & ringan pak, karena 0,5\% \\
\hline 16 & ringan dan praktis \\
\hline & \\
\hline
\end{tabular}

\begin{tabular}{|l|l|}
\hline 17 & Mudah menghitungnya pak \\
\hline 18 & $\begin{array}{l}\text { Simple tapi mala harus datang ke kntor } \\
\text { pajak karena belum paham caranya }\end{array}$ \\
\hline 19 & Relatif simple pak \\
\hline 20 & cukup ringan, karena 0,5 \\
\hline
\end{tabular}

Berdasarkan hasil wawancara di atas maka dapat disimpulkan bahwa PP No. 23 Tahun 2018 meringankan UMKM di Kota Banjarbaru dalam membayar pajak, akan tetapi PP No. 23 Tahun 2018 tersebut belum bisa dikatakan efektif karena wajib pajak masih belum memanfaatkan fasilitas tersebut. Hal tersebut dikuatkan dengan data pada Tabel 1.7 yang peneliti peroleh dari KPP Pratama XYZ di Provinsi Kalimantan Selatan saat wawancara dengan Partisipan 21 selaku Kepala seksi di KPP Pratama XYZ di Provinsi Kalimantan Selatan dengan pertanyaan sebagai berikut: "Bagaimana menurut bapak kefektifan PP No 23 Tahun 2018, apakah sudah mampu meningkatkan kontribusi pajak dari UMKM?"

Berdasarkan data yang ada menurut saya belum mas, karena kontribusi pajak dari UMKM masih kecil bila dibandingkan dengan total penerimaan pajak di KPP Pratama XYZ di Provinsi Kalimantan Selatan. Kontribusi UMKM cuman sekitar 1\% Mas di tahun 2018, dan menurun di 2019.

\section{Tabel 1.7 Target dan Realisasi Penerimaan Paja KPP Banajarbaru 2018-2019}

\begin{tabular}{|c|c|c|c|c|}
\hline Target 2018 & $\begin{array}{c}\text { Realisasi } \\
\mathbf{2 0 1 8}\end{array}$ & Target 2019 & $\begin{array}{c}\text { Realisasi } \\
\mathbf{2 0 1 9}\end{array}$ & $\begin{array}{c}\text { Ketera } \\
\text { ngan }\end{array}$ \\
\hline $\begin{array}{c}1,925,878,987 \\
, 000\end{array}$ & $\begin{array}{c}1,964,669,4 \\
33,429\end{array}$ & $\begin{array}{c}2,411,913,73 \\
2,000\end{array}$ & $\begin{array}{c}2,697,784,82 \\
3,391\end{array}$ & $\begin{array}{c}\text { Kode } \\
420 \\
\text { adalah } \\
\text { UMKM }\end{array}$ \\
\hline \multicolumn{4}{|c|}{ Realisasi Pembayaran Pajak UMKM } \\
\cline { 1 - 3 } $\begin{array}{c}\text { Kode 420 Th } \\
2018\end{array}$ & Persentasse & $\begin{array}{c}\text { Kode } 420 \text { Th } \\
2019\end{array}$ & Persentasse & \\
\cline { 1 - 3 } $14,713,588,86$ & $1 \%$ & $9,820,591,28$ & $0.4 \%$ & \\
9 & & 2 & \\
\hline
\end{tabular}

Sumber: Pratama XYZ di Provinsi Kalimantan Selatan, 2020

Hasil wawancara diatas menunjukkan bahwa kontribusi pajak dari UMKM pada 
tahun 2018 hanya 1\% dari realisasi target penerimaan pajak. Sedangkan pada tahun 2019 kontribusi pajak dari UMKM mengalami penurunan dari tahun sebelumnya, kontribusinya hanya $0,4 \%$ dari realisasi target penerimaan pajak Pratama XYZ di Provinsi Kalimantan Selatan.

\section{Peran Pemerintah Dalam Meningkatkan Kepatuhan UMKM}

Kontribusi penerimaan pajak terhadap penerimaan pemerintah diharapkan selalu meningkat. Akan tetapi fenomena yang ada di Kota Banjarbaru masih banyak wajib pajak yang tidak patuh dalam membayar pajak. Hal ini pasti akan mempengaruhi penerimaan pemerintah dari sektor pajak.

Berdasarkan informasi dari Partisipan 21 selaku Kepala Seksi pengawasan dan konsultasi KPP Pratama XYZ di Provinsi Kalimantan Selatan, langkah-langkah yang diambil oleh pemerintah adalah sebagai berikut:

(1) Pengawasan pembayaran masa / bulanan terhadap Wajib Pajak yang tertib maupun yang belum

(2) Mengoptimalkan pemanfaatan data yang sudah dari data internal dan eksternal lainnya

(3) Kegiatan penelitian administrasi atas himbauan yang masih outstanding

(4) Analisa laporan keungan dan melakukan pemanggilan konseling atas Wajib Pajak yang memiliki kecenderungan tidak patuh

(5) Menerbitkan sanksi bagi Wajib Pajak yang telat bayar maupun lapor

(6) Meningkatkan kegiatan ekstensifikasi dan intensifikasi perpajakan

Selain langkah-langkah diatas, pemerintah berusaha memberikan pelayanan yang baik kepada wajib pajak. Peningkatan kualitas dan kuantitas pelayanan diharapkan dapat meningkatkan kepuasan kepada wajib pajak sebagai pelanggan sehingga meningkatkan kepatuhan dalam bidang perpajakan.

\section{Kesimpulan dan Saran}

Kesimpulan

Berdsarkan hasil penelitian dan pembahasan maka kesimpulan dalam penelitian ini adalah sebagai berikut:

1. UMKM di Kota Banjarbaru cukup baik dalam memahami peraturan perpajakan, khususnya tentang peraturan No 23 Tahun 2018. Namun pemahaman yang dimiliki oleh UMKM baru sebatas pada PP tersebut sangat meringankan UMKM dalam membayar pajak, karena hanya dikenai tariff $\mathrm{PPh}$ final sebesar $0.5 \%$ yang sebelumnya sebesar $1 \%$.

2. Potensi kepatuhan UMKM di Kota Banjar Baru Kalimantan Selatan dalam membayar pajak masih rendah, meskipun mereka memahami tentang peraturan perpajakan.

3. Efektivitas PP No. 23 Tahun 2018 di Kota Banjarbaru belum bisa dikatakan efektif karena belum ada peningkatan wajib pajak UMKM yang signifikan. PP yang disahkan pada pertengahan tahun 2018 ini dirasakan masih kurang sosialisasi kepada para wajib pajak.

4. Menambah sarana edukasi dan kampanye perpajakan untuk menunjukkan citra positif pemerintah dalam mengelola dan menggunakan dana pajak.

\section{Saran}

Berdasarkan kesimpulan diatas, maka saran yang diberikan peneliti adalah sebagai berikut:

1. Meningkatkan pemahaman wajib pajak terhadap peraturanperaturan tentang perpajakan. Pemahaman tersebut tidak hanya sebatas pada pemotongan $\mathrm{PPh}$ final dari $1 \%$ menjadi $0,5 \%$. 
2. Menumbuhkan kepercayaan kepada wajib pajak akan pengelolaan dana pajak agar kesadaran dalam membayar pajak meningkat.

3. Perlunya sosialisasi yang lebih gencar tentang PP No 23 Tahun 2018

4. Mengimplementasikan dana pajak untuk kepentingan publik seperti memperbaiki fasilitas publik, meningkatkan kenyamanan fasilitas publik. Transparan dalam penggunaan dana pajak.

\section{Daftar Pustaka}

Anggara, A. B., \& Sulistiyanti, U. (2017).

Kepatuhan Pajak Usaha Mikro, Kecil dan Menengah di Surakarta.

Simposium Nasional Akuntansi XX Jember, 2017. Jember:

https://www.researchgate.net/.

Anthony, K. (2019, Juli 26). CNBC Indonesia. Retrieved frm CNBC Indonesia Web Site:https://www.cnbcindonesia.com/n ews/20190726094730-4-87743/miristernyata-tax-ratio-indonesia-terendahdi-asia-pasifik

As'ari, N. G., \& Erawati, T. (2018). PENGARUH PEMAHAMAN PERATURAN PERPAJAKAN, KUALITAS PELAYANAN, KESADARAN WAJIB PAJAK DAN SANKSI PAJAK TERHADAP KEPATUHAN WAJIB PAJAK ORANG PRIBADI (Studi Empiris pada Wajib Pajak Orang Pribadi Kecamatan Rongkop). AKUNTANSI DEWANTARA, VOL. 2 NO. 1.

Gunadi, T. N., Millla, S. S., \& Wisamodro, J. (2010). Harmonisasi Pajak Tidak Langsung Atas Konsumsi di NegaraNegara Anggota ASEAN. Jurnal Ilmu Administrasi dan Organisasi.

Gustomo, M. (2018, Maret 20). Menciptakan Pajak yang Ramah untuk UMKM. Retrieved from https://www.kemenkeu.go.id/: https://www.kemenkeu.go.id/publikasi /artikel-dan-opini/menciptakan-pajakyang-ramah-untuk-umkm/

Katadata. (2018, Desember 12). D Katadata. Retrieved from Databoks web site: https://databoks.katadata.co.id/datapub lish/2018/12/12/rasio-pajakindonesiakalah-dibanding-dengannegara-lainnya

Kemenkeu. (2019, November 27). Dkatadata. Retrieved from Databoks web site: https://databoks.katadata.co.id/datapub lish/2019/11/27/oktober-2019realisasi-penerimaan-pajak-masih6571-dari-target-apbn-2019

Muc Consulting. (2019, May 2). Muc Consulting. Retrieved from Muc Consulting web site: https://mucglobal.com/news/read/1247 /kontribusi-pajak-umkm-masih-sangatrendah

Sahban, H. (2015). Menembus badai UMKM. Makasar: CV. Sah Media.

Sekretariat Jenderal DPR RI. (2019, November 5). DEWAN PERWAKILAN RAKYAT. Retrieved from DEWAN PERWAKILAN RAKYAT Web site: http://www.dpr.go.id/berita/detail/id/2 6350/t/DJP+Selalu+Gagal+Kejar+Tar get

Siat, C. C., \& Toly, A. A. (2013). FaktorFaktor yang Mempengaruhi Kepatuhan Wajib Pajak dalam Memenuhi Kewajiban Membayar Pajak di Surabaya. $T A X \&$ ACCOUNTING REVIEW, VOL.1, NO.1.

Sudiartana, I. M., \& Mendra, N. P. (2017). Faktor - Faktor Yang Mempengaruhi Kepatuhan Wajib Pajak. Strengthening Economic for Global Competitiveness (pp. 184-195). Denpasar: Public Knowledge Project .

Sugiyono. (2013). Metode Penelitian Kuantitaif, Kualitatif, dan $R \& D$. Bandung: CV Alfabeta.

Widayati, \& Nurlis. (2010). Faktor-Faktor Yang Mempengaruhi Kemauan Untuk Membayar Pajak Wajib Pajak Orang 
Pribadi Yang Melakukan Pekerjaan

Bebas ( Studi Kasus Pada Kpp

Pratama Gambir Tiga ). Symposium

Nasional Akuntansi XIII , Universitas

Jenderal Soederman, Purwokerto.

\section{Dokumen}

Republik Indonesia, Undang -Undang Nomor 28 Tahun 2007 Tentang Perubahan Ketiga Atas Undangundang Nomor 6 Tahun 1983 Tentang Ketentuan Umum dan Tata Cara Perpajakan.

Peraturan Menteri Keuangan Nomor 192/PMK.03/2007 Tentang Tata Cara Penetapan Wajib Pajak Dengan Kriteria Tertentu Dalam Rangka Pengembalian Pendahuluan Kelebihan Pembayaran Pajak.

Peraturan Pemerintah (PP) No 23 Tahun 2018 Tentang Pajak Penghasilan Atas Penghasilan Dari Usaha Yang Diterima Atau Diperoleh Wajib Pajak Yang Memiliki Peredaran Bruto Tertentu. 